\title{
INITIAL GROWTH OF Campomanesia adamantium (CAMBESS.) O. BERG. SEEDLINGS ON SUBSTRATES WITH DIFFERENT COMPOSITIONS AND WATER RETENTION CAPACITIES
}

\author{
CRESCIMENTO INICIAL DE MUDAS DE Campomanesia adamantium (CAMBESS.) \\ O. BERG EM DIFERENTES SUBSTRATOS E CAPACIDADE DE RETENÇÃO DE \\ $A ́ G U A$
}

\author{
Daiane Mugnol DRESCH ${ }^{1}$; Silvana de Paula Quintão SCALON² ${ }^{2}$ Rosilda Mara MUSSURY³; \\ Flávia Mitsuko KODAMA ${ }^{4}$ \\ 1. Pós-Doutoranda em Agronomia (PNPD/CAPES), Universidade Federal da Grande Dourados - UFGD, Dourados, MS, Brasil. \\ daiamugnol@ hotmail.com; 2. Bolsista Produtividade em Pesquisa CNPq/Professora da Faculdade de Ciências Agrárias - UFGD, \\ Dourados, MS, Brasil; 3. Professora da Faculdade de Ciências Biológicas e Ambientais - UFGD, Dourados, MS, Brasil; 4. Mestre em \\ Biologia Geral (Bioprospeção), Faculdade de Ciências Biológicas e Ambientais - UFGD, Dourados, MS.
}

\begin{abstract}
Information on germination, seedling development, and substrates and water requirements of native Savannah species are scarce, for propagation and plantation establishments. Based on this, we evaluated the initial growth of Campomanesia adamantium seedlings sown into tubes containing substrates with different compositions and water retention capacities, including red latosoil; red latosoil and Bioplant ${ }^{\circledR}$ (1:1); red latosoil, sand, and semidecomposed poultry manure (1:1:0.5); red latosoil and sand (1:1); and red latosoil, sand, and semidecomposed poultry manure (1:2:0.5). The tubes were irrigated three times per week to $25 \%, 50 \%, 75 \%$, and $100 \%$ of their water retention capacities. The morphological characteristics of the seedlings and their quality indexes were analyzed 52, 83, 114, and 145 days after sowing. We tested all possible combinations of substrates and percentages of water holding capacities, with four replicates (12 tubes). The substrates of red latosoil plus sand and red latosoil plus Bioplant ${ }^{\circledR}$ were found to be most suitable for the growth and development of $C$. adamantium seedlings at water retention capacities between $75 \%$ and $100 \%$. Growing conditions with water retention capacities of $25 \%$ and $50 \%$ should not be used to produce seedlings of C. adamantium.
\end{abstract}

KEYWORDS: Myrtaceae. Guavira. Savannah. Water stress.

\section{INTRODUCTION}

The growing global demand for Brazilian fruits has stimulated interest and research focusing on native fruits from the Savannah biome (SANTOS et al., 2006). Campomanesia sp., popularly known as guavira or gabiroba, is native to Brazil and is widely abundant in the Savannah regions. Scalon et al. (2013) noted in their review that the leaves and fruits of Campomanesia sp. have anti-inflammatory, antidiuretic, and antiseptic properties; the fruits are very flavorful, have high concentrations of vitamins, and can be used for making liquors.

Despite the growing interest in native Savannah species, there is very little information currently available concerning their germination, seedling development, and substrate and water requirements for successful propagation. The establishment of any plant from seed will greatly depend on the substrate used to facilitate seed germination and on seedling emergence and quality, among other factors (WAGNER JUNIOR et al., 2006; ALEXANDRE et al., 2006). The diversity of substrates is large, and several types of substrates are available, including pure or mixed forms, which vary in price and quality; however, there is no ideal substrate for all conditions and species (TRAZZI et al., 2012).

Plant-water relationship studies can help us to better understand the processes of absorption, transport, and water loss and can provide insights into plant strategies for survival in environments with little, or excessive, soil water. The quantity of water stored and available to plants varies according to substrate texture and other physical characteristics, and plants will demonstrate different morphophysiological responses accordingly (KIEHL, 1979; MEDRI, 2002; SCALON and JEROMINI, 2013).

Oliveira and Joly (2010) and Chaves et al. (2002) emphasized that the effects of water deficits on different plant species depend on deficit intensity and duration and on the genetic capacity of the plants to respond to environment changes. Waterstressed plants initially demonstrate turgidity losses, decreased growth, and reduced synthesis of abscisic acid (ABA), leading to the closing of their stomata and eventual leaf abscission (LARCHER, 2006). 
Excessive soil water also reduces plant growth and development. Saturated soils show reduced oxygen levels, provoking anaerobic respiration in the roots and eventually the death of root cells due to acidosis. The consequences of anaerobic conditions include reduced root growth and poor water and nutrient absorption (FLOSS, 2008; OLIVEIRA and JOLY, 2010).

Based on these observations, in the present study we evaluated the initial growth of $C$. adamantium seedlings on different substrates and at different water retention capacities.

\section{MATERIAL AND METHODS}

Fruits of Campomanesia adamantium were collected at the end of September 2009 from 20 plants growing in a region of Savannah vegetation on the Santa Madalena Farm in the municipality of Dourados (elevation: $452 \mathrm{~m}$, latitude: $22^{\circ} 08^{\prime} 25^{\prime \prime} \mathrm{S}$, longitude: $55^{\circ} 58^{\prime} 20^{\prime \prime} \mathrm{W}$ ), Mato Grosso do Sul State, Brazil. Mature fruits were transported to the Plant Nutrition and Metabolism Laboratory at Grande Dourados Federal University (UFGD) and stored for 3 days in a refrigerator $\left(5 \pm 2{ }^{\circ} \mathrm{C}\right)$. The seeds were manually cleaned by washing in running water and were subsequently dried for $15 \mathrm{~min}$ on paper towels at room temperature $\left(25 \pm 1{ }^{\circ} \mathrm{C}\right.$ and $60 \%$ relative humidity). Malformed or broken seeds were discarded.

All experiments were performed during the period between October 2009 and April 2010 in a greenhouse (6 feet tall, covered by shade net $[70 \%$ shade]), at the Faculty of Agrarian Sciences at UFGD in the municipality of Dourados, Mato Grosso do Sul State, Brazil.

Single seeds were sown in $50 \mathrm{~mm} \times 190$ $\mathrm{mm}$ tubes containing the following substrates $(\mathrm{S})$ : red latosoil (LS; red distroferric latosoil with a clay texture); red latosoil plus Bioplant 1:1 (LS+BIO); red latosoil, sand, and semidecomposed poultry manure 1:1:0.5 (LS+S+PM1); red latosoil and sand 1:1 (LS+S); or red latosoil, sand, and semidecomposed poultry manure 1:2:0.5 (LS+S+PM2). The chemical compositions of these substrates are listed in Table 1. The experiment was conducted under a plastic cover 3 feet tall, and the tubes were placed $0.5 \mathrm{~m}$ above the soil.

Table 1. Chemical analyses of the substrates red latosoil (LS) (red distroferric latosoil with a clay texture), red latosoil + Bioplant ${ }^{\circledR}(\mathrm{LS}+\mathrm{BIO})$, red latosoil + sand + semi-decomposed poultry manure $(\mathrm{LS}+\mathrm{S}+\mathrm{CF} 1$ 1:1:0.5), red latosoil + sand $(\mathrm{LS}+\mathrm{S})$, or red latosoil + sand + semi-decomposed poultry manure (LS+S+CF2 - 1:2:0.5) utilized in the germination experiments with Campomanesia adamantium.

\begin{tabular}{cccccccccccc}
\hline Substrates & \multicolumn{10}{c}{ Attributes of substrates } \\
\hline & $\begin{array}{c}\mathrm{OM}^{1 / \mathrm{A}} \\
\mathrm{g} / \mathrm{dm}^{3}\end{array}$ & $\begin{array}{l}\mathrm{pH}^{2} \\
\mathrm{CaCl}_{2}\end{array}$ & $\begin{array}{l}\mathrm{P}^{3 / \mathrm{B}} \\
\mathrm{mg} / \mathrm{dm}^{3}\end{array}$ & $\mathrm{~K}^{4 / \mathrm{B}}$ & $\mathrm{Ca}^{5 / \mathrm{C}}$ & $\mathrm{Mg}^{6 / \mathrm{C}}$ & $\mathrm{H}+\mathrm{Al}^{7}$ & $\mathrm{SB}^{8}$ & $\mathrm{CEC}^{9}$ & $\begin{array}{l}\mathrm{BS}^{10} \\
\%\end{array}$ \\
\hline LS & 13.2 & 3.8 & 1.0 & 2.4 & 14.0 & 5.0 & 105 & 21.4 & 126.4 & 16.0 \\
LS+BIO & 84.0 & 4.6 & 51.0 & 16.0 & 59.0 & 41.0 & 80.0 & 116.0 & 196.0 & 59.0 \\
LS+S+PM1 & 3.0 & 6.1 & 267.0 & 56.0 & 28.0 & 27.0 & 19.0 & 111.0 & 130.0 & 85 \\
LS+S & 3.9 & 4.4 & 0.0 & 1.5 & 17.0 & 7.0 & 36.0 & 25.5 & 61.5 & 41.0 \\
LS+S+PM2 & 3.9 & 5.6 & 131.0 & 25.5 & 21.0 & 15.0 & 18.0 & 61.5 & 79.5 & 77.0 \\
\hline
\end{tabular}

${ }^{1} \mathrm{OM}$ : Organic matter (grams per cubic decimeter); ${ }^{2} \mathrm{pH} \mathrm{CaCl}_{2}$ : centimolar $\mathrm{pH}$ in solution of chlorine. Calcium; ${ }^{3} \mathrm{P}$ : Phosphorus extracted from soil by Mehlich; ${ }^{4} \mathrm{~K}$ : Potassium. exchangeable forms; ${ }^{5} \mathrm{Ca}$ : Calcium. exchangeable forms; ${ }^{6} \mathrm{Mg}$ : Magnesium. exchangeable forms; ${ }^{7} \mathrm{H}+\mathrm{Al}$ : Potential acidity; ${ }^{8} \mathrm{SB}$ : Sum of bases; ${ }^{9}$ CEC: Cation exchange capacity; ${ }^{10}$ BS - Soil base saturation index; ${ }^{A}$ Methods of Walkley and Black (JACKSON, 1976); ${ }^{\mathrm{B}}$ Extractor Mehlich 1 (BRAGA and DEFELIPO, 1974) and ${ }^{\mathrm{C}}$ Extractor 1 N KCL (VETTORI, 1969).

The Bioplant substrate is composed of pine bark chips, aggregating agents, vermiculite, coconut fiber, and mineral complements (NPK + MICRO in proportions that are not disclosed by the manufacturer), with a $\mathrm{pH}$ between 5.2 and 6.5 and an electrical conductivity of $0.6-1.4 \mu \mathrm{S} \mathrm{cm}^{-1}$.

The water retention capacity (WRC) of each substrate was determined by measuring the amount of water retained by the freely drained substrate (SOUZA et al., 2000). The growth tubes were then weighed individually three times per week, and, based on the mass of the plant, sufficient water was added to each tube to reach $25 \%, 50 \%, 75 \%$, and $100 \%$ of their WRCs.

The analyses were performed with seedlings at 52,83,114, and 145 days after sowing (DAS), utilizing 12 plants per repetition. The following characteristics were evaluated: shoot length (SL) and root length (RL; both expressed in $\mathrm{cm}$ ); numbers of leaves (NL; obtained by counting the total number of leaves per plant); total chlorophyll index (SPAD units; determined using a Konica- 
Minolta SPAD 502 chlorophyll meter); shoot dry weight (SDW) and root dry weight (RDW; obtained by drying the plant material in a forced-air oven at $60^{\circ} \mathrm{C}$ for $72 \mathrm{~h}$ to a stable weight, expressed in $\mathrm{mg}$ plant-1, using a precision balance $[ \pm 0.0001 \mathrm{~g}])$. The Dickson Quality Index (DQI) was determined using the methodology (modified) described by Dickson et al. (1960), where DQI $=\mathrm{TDW} /(\mathrm{SL} / \mathrm{SD}+$ SDW/RDW), in which TDW is the total dry weight, SL is the shoot length, SD is the stem diameter, SDW is the shoot dry weight, and RDW is the root dry weight.

The statistical procedure used was a completely randomized experiment with a factorial design $5 \times 4 \times 4$ (substrates $\times$ water retention capacity $\times$ days after sowing). All possible combinations of substrates and water saturation levels were made, with four replicates (12 tubes). The results were subjected to analyses of variance and the Tukey test, and the averages of the evaluation periods were adjusted using regression equations and analyzed utilizing SISVAR software (FERREIRA, 2008). Differences with $P$ values of less than 0.05 were considered significant.

\section{RESULTS}

Interactions between $\mathrm{S}$ and WRC, $\mathrm{S}$ and DAS, WRC and DAS were significant for all variables analyzed except for the interaction between WRC and DAS in the number of leaves was not significant (Table 2).

Table 2. Summary of the analysis of variance for values of shoot length (SL), root length (RL), numbers of leaves (NL), chlorophyll index (CI), shoot dry weight (SDW), root dry weight (RDW) and Dickson Quality Index (DQI) of Campomanesia adamantium seedlings sown into different substrates (S), water retention capacities (WRC) and days after sowing (DAS).

\begin{tabular}{cccccccc}
\hline Sources of & \multicolumn{7}{c}{ Mean square } \\
\cline { 2 - 7 } variation & SL & RL & NL & CI & SDW & RDW & DQI \\
\hline S & $269.23^{*}$ & $2941.91^{*}$ & $491.68^{*}$ & $9444.73^{*}$ & $121904.58^{*}$ & $37441.81^{*}$ & $0.0087^{*}$ \\
WRC & $102.48^{*}$ & $645.22^{*}$ & $157.28^{*}$ & $3001.32^{*}$ & $42698.06^{*}$ & $9385.57^{*}$ & $0.0028^{*}$ \\
DAS & $3.30^{*}$ & $166.22^{*}$ & $19.19^{*}$ & $227.78^{*}$ & $52793.94^{*}$ & $27353.93^{*}$ & $0.0063^{*}$ \\
S x WRC & $14.52^{*}$ & $129.81^{*}$ & $16.19^{*}$ & $749.03^{*}$ & $11474.77^{*}$ & $3028.44^{*}$ & $0.0007^{*}$ \\
S x DAS & $4.86^{*}$ & $16.14^{*}$ & $13.95^{*}$ & $189.41^{*}$ & $27183.62^{*}$ & $8871.97^{*}$ & $0.0023^{*}$ \\
WRC x DAS & $8.10^{*}$ & $36.6^{*}$ & $6.14^{\text {ns }}$ & $243.7^{*}$ & $8279.02^{*}$ & $2405.94^{*}$ & $0.0007^{*}$ \\
\hline Mean & 2.78 & 8.18 & 3.39 & 18.01 & 42.72 & 23.72 & 0.0123 \\
\hline CV $(\%)$ & 38.92 & 31.52 & 69.87 & 39.83 & 74.59 & 67.74 & 71.67 \\
\hline
\end{tabular}

* Significant, ${ }^{\text {ns }}$ not significant at $5 \%$ probability, by $\mathrm{F}$ test, $\mathrm{CV}$ coefficient of variation.

The shoot length of seedlings germinated on the LS+BIO and LS+S substrates exhibited a quadratic fit, with WRCs of $81.68 \%(6.99 \mathrm{~cm})$ and $74.96 \%(5.96 \mathrm{~cm})$, respectively (Figure 1A), representing the best conditions for $C$. adamantium seedling development.

The substrates $\mathrm{LS}+\mathrm{BIO}$ and $\mathrm{LS}+\mathrm{S}$ promoted the greatest increases in shoot growth during the 145 days of the experiments $(6.39 \mathrm{~cm}$ and $5.3 \mathrm{~cm}$, respectively) (Figure 1B). In the interactions between water retention capacity and days after sowing, the treatments with $100 \%$ and $75 \%$ WRC showed the greatest growths of the shoot of the plants, although the $75 \%$ WRC did not show any length variations as a function of the days after sowing (Figure 1C).
Root growth was most obvious when seedlings were grown on $\mathrm{LS}+\mathrm{BIO}, \mathrm{LS}+\mathrm{S}$, and $\mathrm{LS}$ at $80.64 \%(19.68 \mathrm{~cm}), 97.09 \%(19.77 \mathrm{~cm})$, and $100 \%$ $(16.18 \mathrm{~cm})$ WRC, respectively (Figure 1D). Root depths and root spreading distances were greater with higher substrate water contents, and the number of root hairs also increased under these same conditions (data not presented). Greater root growth was observed in the $\mathrm{LS}+\mathrm{S}$ substrate at 130 days after sowing $(20.21 \mathrm{~cm})$ and in LS+BIO at 140 days after sowing $(17.70 \mathrm{~cm}$; Figure 1E). In Figure $1 \mathrm{~F}$, the root growth was continuous throughout the evaluation period, but showed lower development in water deficit conditions ( $25 \%$ and 50\% WRC). 
A)

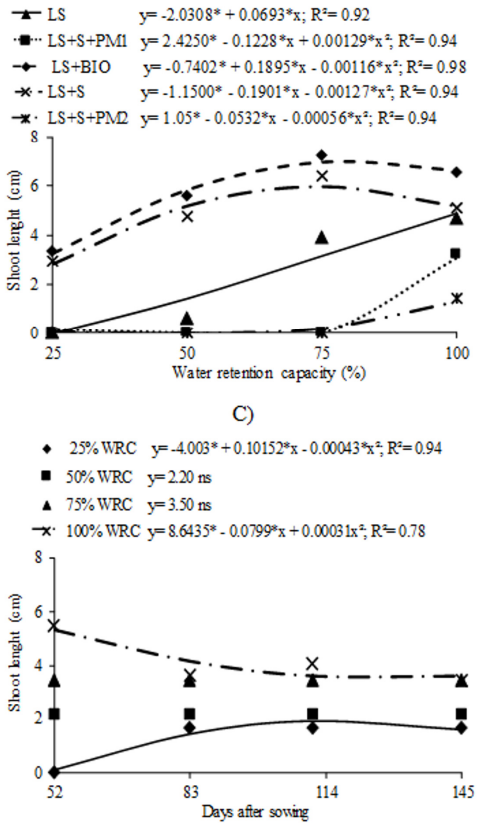

E)

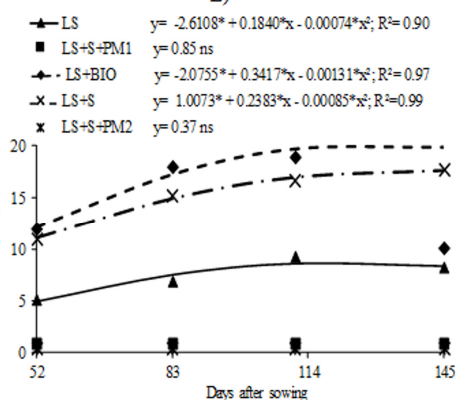

$\begin{array}{ll}\text { LS } & y=2.30 \mathrm{~ns} \\ - \text { LS+S+PMl } & y=1.9440^{*}-0.0116^{*} ; R^{2}=0.76 \\ \rightarrow \text { LS+BIO } & y=4.1897^{*}+0.01522^{*} ; R^{2}=0.57\end{array}$

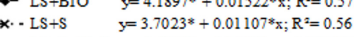

*. LS+S+PME $y=1.9728^{*}-0.0550^{*} \mathrm{x}+0.00035^{*} \mathrm{x}^{2} \cdot \mathrm{R}^{2}=0.95$

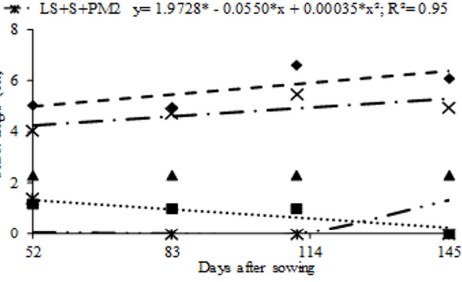

D)

- LS $\quad \mathrm{y}=-7,36875^{*}+0.2355^{*} * \mathrm{R}^{2}=0.90$

-.. $\mathrm{LS}+\mathrm{S}+\mathrm{PM1} \mathrm{y}=2.550^{*}-0.1292 * x+0.0013^{*} ; \mathrm{R}^{2}=0.94$

- - LS+BIO $\quad \mathrm{y}=6.0248^{*}+0.3387 \% \mathrm{x}-0.0021^{*} \mathrm{x}^{2} \mathrm{R}^{2}=0.99$

$-x-$ LS+S $\quad y=-0.0662^{*}+0.4078^{*} x-0.0021 * x ; R^{2}=0.98$

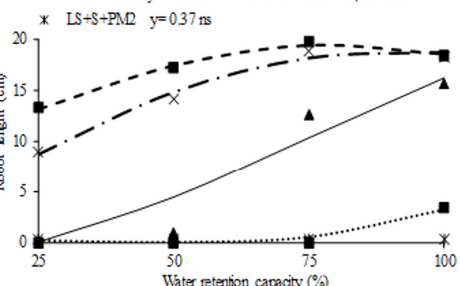

F)

$\rightarrow 25 \%$ WRC $y=-13.3162^{*}+0.3332^{*} \mathrm{x}-0.00137 \mathrm{x}^{2}, \mathrm{R}^{2}=0.94$

- $50 \%$ WRC $y=4.6156^{*}+0.01912 \% ; R^{2}=0.87$

$-\$-75 \%$ WRC $y=6.1903 *+0.04168 * R^{2}=0.87$

$-x-100 \%$ WRC $y=8.4990^{*}+0.03090^{*} x ; R^{2}=0.92$

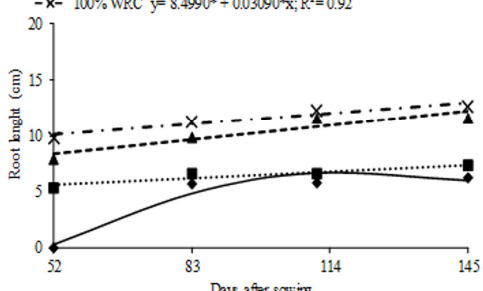

Figure 1. Lengths shoot $(\mathrm{cm})(\mathrm{A}, \mathrm{B}, \mathrm{C})$ and root lengths $(\mathrm{cm})$ over time $(\mathrm{D}, \mathrm{E}, \mathrm{F})$ of Campomanesia adamantium seedlings subjected to different substrates $\mathrm{x}$ water retention capacity (\%) (A and D), substrates $\mathrm{x}$ days after sowing (B and $\mathrm{E}$ ) and water retention capacity (\%) $\mathrm{x}$ days after sowing (C and F).

In relation to the numbers of leaves, the greatest values were observed with the substrates $\mathrm{LS}+\mathrm{BIO}$ and $\mathrm{LS}+\mathrm{S}$ at $100 \% \mathrm{WRC}$ after 145 days of cultivation (Figure 2A, B). Under conditions of deficient water availability (25\% and 50\% WRC) the NL produced by $C$. adamantium seedlings was reduced (Figure 2A).

At $100 \%$ water saturation, the plants could absorb greater quantities of water, allowing greater plant development with more photosynthetic leaves. Plants suffering from water deficits showed reduced numbers of leaves in all of the tested substrates (Figure 2A).

The substrates $\mathrm{LS}+\mathrm{BIO}$ and $\mathrm{LS}+\mathrm{S}$ under $74.38 \%$ (36.30 SPAD units) and 100\% (34.16
SPAD units) WRC, respectively, showed the greatest chlorophyll content indices. Moreover, the greatest reduction in SPAD value was observed in seedlings grown on the LS+BIO substrate at high water saturation levels (100\% WRC) (Figure 2C, E). Reduced chlorophyll contents were observed under conditions of low water availability in the present work (Figure 2E).

The LS+BIO LS-+S substrates gave the highest chlorophyll indices after 145 and 114 days of cultivation, respectively (Figure 2D). The chlorophyll index did not vary over time in substrates at $100 \%$ WRC, remaining at an average of 27.19 (Figure 2E). 
Initial growth of...

DRESCH, D. M. et al.

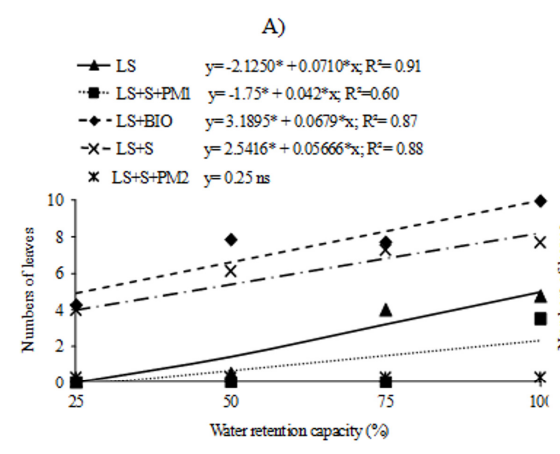

C)
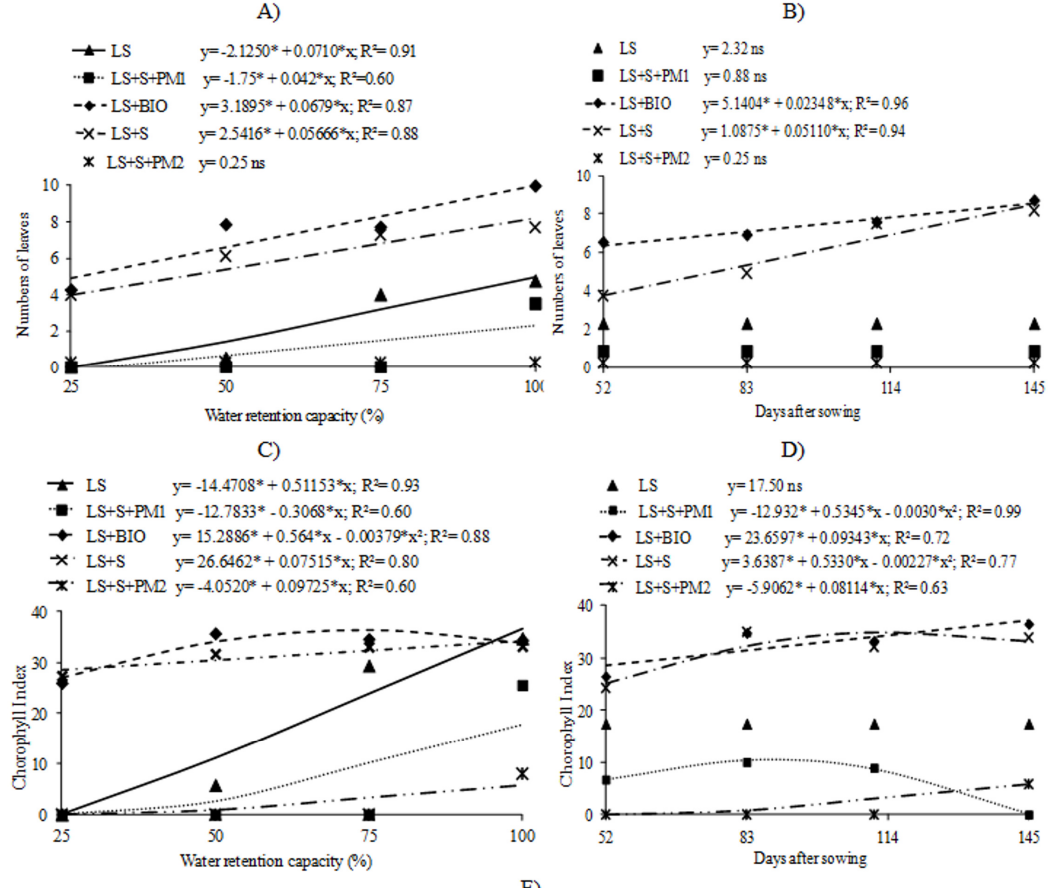

D)

A LS $y=17.50 \mathrm{~ns}$

$\rightarrow$ LS+BIO $\mathrm{y}=23.6597^{*}+0.09343^{*} \mathrm{x} ; \mathrm{R}^{2}=0.72$

$\begin{array}{ll}\text { - LS+BIO } & y=23.6597^{*}+0.09343^{*} \mathrm{x} ; \mathrm{R}^{2}=0.72 \\ -\mathrm{L}-\mathrm{LS}+\mathrm{S} & \mathrm{y}=3.6387^{*}+0.5330^{*} \mathrm{x}-0.00227^{*} \mathrm{x}^{2} ; \mathrm{R}^{2}=0.77\end{array}$

$\begin{array}{lll}-x \cdot L S+S & y=3.6387^{*}+0.5330^{*} x-0.002277^{*} \\ -x \cdot L S+S+P M 2 & y=-5.9062^{*}+0.08114^{*} x ; R^{2}=0.63\end{array}$
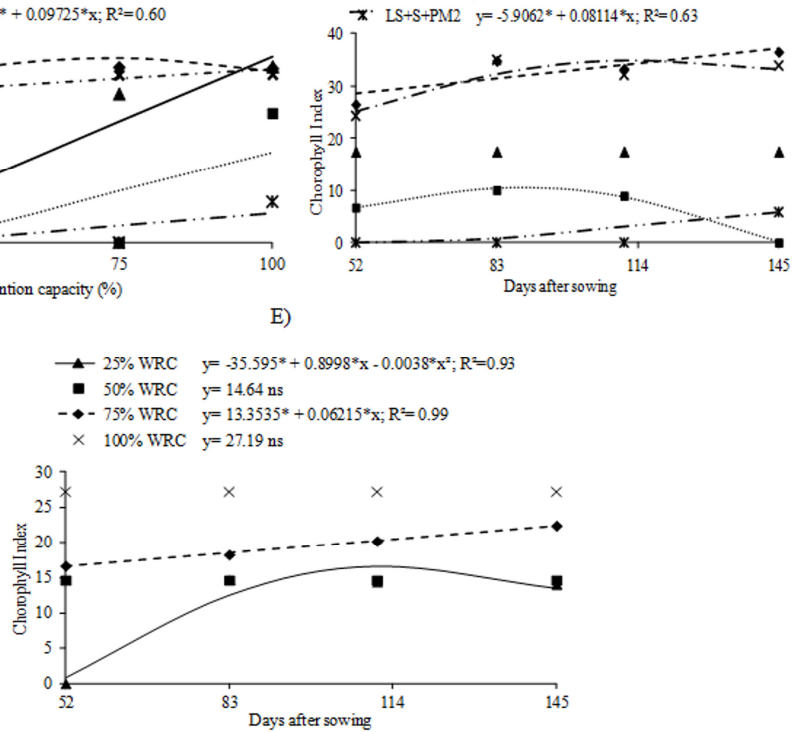

Figure 2. Numbers of leaves (A, B) per plant and the chlorophyll index (SPAD units) (C, D, E) of Campomanesia adamantium seedlings subjected to different substrates $\mathrm{x}$ water retention capacity $(\%)(\mathrm{A}$ and $\mathrm{C})$, substrates $\mathrm{x}$ days after sowing (B and D) and water retention capacity (\%) $\mathrm{x}$ days after sowing (E).

The shoot dry weights of seedlings germinated on the LS+BIO substrate showed the highest weight gains at $83.54 \%$ WRC $(178.85 \mathrm{mg}$ seedling ${ }^{-1}$ ), with the highest weights being seen after 145 days of cultivation (Figure 3A, B). However, the dry weight values decreased at $100 \%$ WRC using the same substrate, and although these seedlings had greater numbers of leaves, their aerial portion lengths were smaller, and they had lower dry weights.

As shown in Figure $3 \mathrm{~B}$, the seedlings germinated in LS+BIO and LS+S substrates showed increasing dry weight accumulation during 145 days of water stress, with the most dramatic increases observed in seedlings germinated on LS+BIO. The same effect was observed in the interaction between WHC and DAS at $75 \%$ and $100 \%$ WRCs (Figure $3 \mathrm{C})$.

The greatest root dry weights of seedlings were observed in the LS+BIO substrate at $71.45 \%$
WRC (92.55 $\mathrm{mg}$ seedling $\left.{ }^{-1}\right)$, followed by LS+S at $81.86 \%$ WRC (53.88 mg seedling ${ }^{-1}$ ) (Figure 3D). The maximum root dry weights was observed after 145 days of cultivation on the substrates LS, $\mathrm{LS}+\mathrm{BIO}$, and $\mathrm{LS}+\mathrm{S}$ (Figure $3 \mathrm{E}, \mathrm{F}$ ); the same behavior was observed in the WRC $\times$ DAS interactions.

The LS+BIO substrate at $69.23 \% \mathrm{WRC}$ and the LS+S substrate at $100 \%$ WRC had the highest DQI values (0.036 and 0.030, respectively; Figure $4 \mathrm{~A})$. The best DQI indices were observed 145 days after sowing in all of the substrates, except $\mathrm{LS}+\mathrm{S}+\mathrm{CF} 1$ and $\mathrm{LS}+\mathrm{S}+\mathrm{CF} 2$ (in which the seedlings grew very poorly overall and did not show significant differences during the evaluation period; Figure 4B). The DQI indices increased linearly with time during cultivation and were most different at 75\% (0.035) and 100\% (0.033) WRC (Figure 4C). 
A)

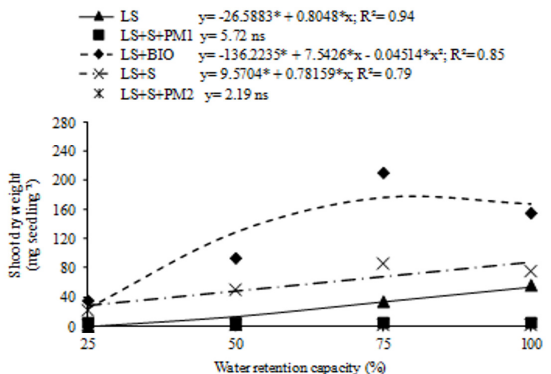

C)

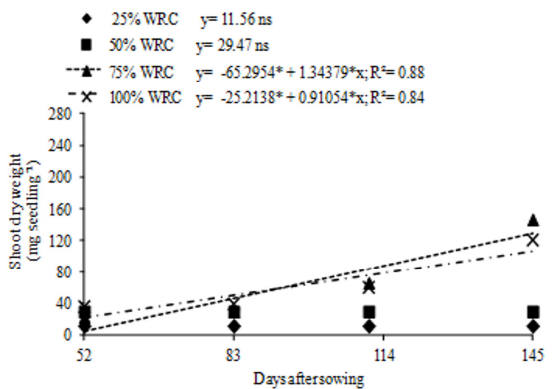

E)

- L LS $\mathrm{y}=-17.4029^{*}+0.33481^{*} \mathrm{x} ; \mathrm{R}^{z}=0.91$

- LS+S+PM1 $y=0.76 \mathrm{~ns}$

- - - LS+BIO $y=-89.4029^{*}+1.5940^{*} x ; R^{*}=0.95$

-x- LS+S $\quad y=-33.846^{*}+0.71347^{\circ} x ; R^{2}=0.98$

* LS+S+PMD $y=0.24 \mathrm{~ns}$

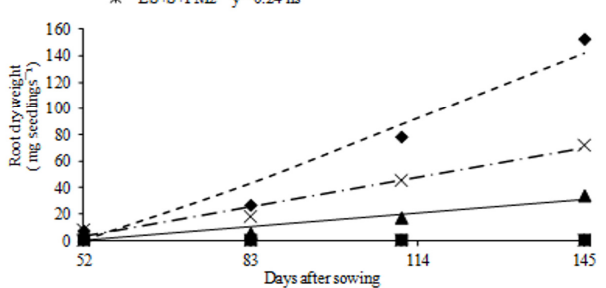

B)

$\begin{array}{ll}\text { LS } & y=23.71 \mathrm{~ns} \\ \text { LSTS+PMI } & y=5.72 \mathrm{~ns}\end{array}$

LS+BIO $\mathrm{y}=132.1042^{*}+2.61577^{*} \mathrm{x}, \mathrm{R}^{2}=0.90$

*. LS+S $\quad y=-26.3931^{*}+0.86765^{*} ; R^{2}=0.99$

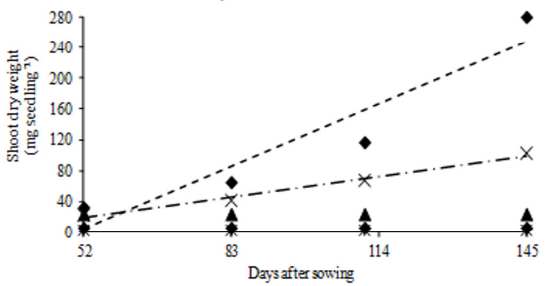

D)

\- LS $\quad y=-19.9770^{*}+0.56483^{*} x ; R^{2}=0.90$

- LS+S+PM1 $y=0.76 \mathrm{~ns}$

- LS+BIO $y=-62.1727^{*}+4.3311^{*} \mathrm{x}-0.03031^{*} \mathrm{x}^{\mathrm{s}}: \mathrm{R}^{2}=0.94$

$-x$ - LS+S $\quad y=-50.2758^{*}+2.5445^{*} x-0.01554^{*} x^{*}, R^{2}=0.86$

* LS+S+PM2 $\mathrm{y}=0.24 \mathrm{n}$

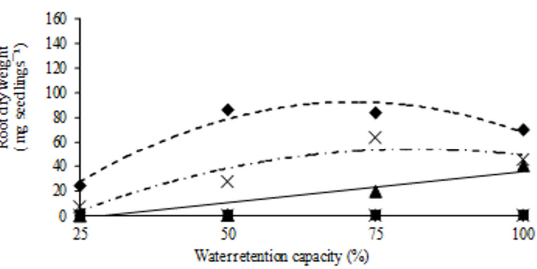

F)

- $25 \%$ WRC $y=5.1 \mathrm{~ns}$

- $-50 \%$ WRC $\quad y=-33.63015^{*}+0.5788^{*} \approx R^{2}=090$

$\perp \cdots 75 \%$ WRC $y=-45.4205^{*}-0.8080^{*} x ; R^{2}=0.92$

$-x-100 \%$ WRC $y=-252884^{*}+0.58672^{*} x ; R^{2}=0.9$

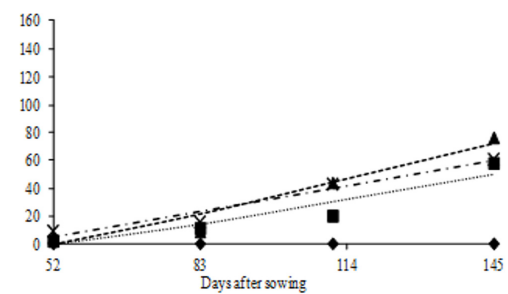

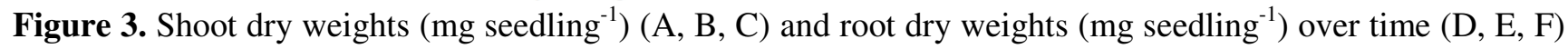
of Campomanesia adamantium seedlings subjected to different substrates $\mathrm{x}$ water retention capacity (\%) (A and D), substrates $\mathrm{x}$ days after sowing (B and $\mathrm{E}$ ) and water retention capacity (\%) $\mathrm{x}$ days after sowing (C and $\mathrm{F})$.

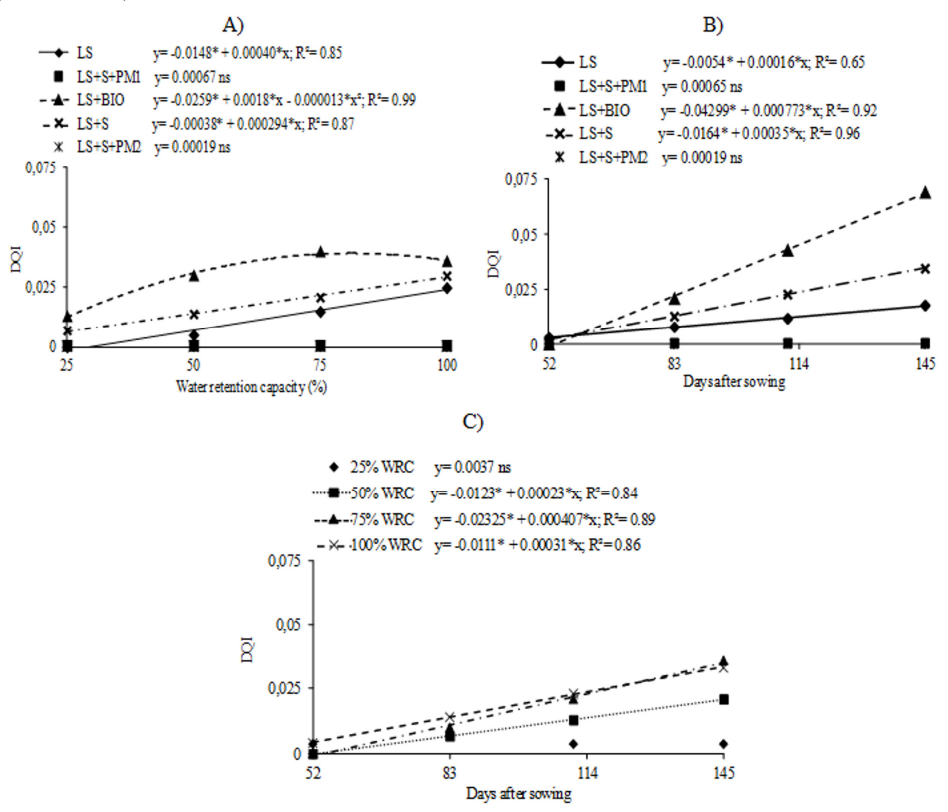

Figure 4. Dickson Quality Index (DQI) (A, B, C) over time of Campomanesia adamantium seedlings subjected to different substrates $\mathrm{x}$ water retention capacity $(\%)(\mathrm{A})$, substrates $\mathrm{x}$ days after sowing $(\mathrm{B})$ and water retention capacity $(\%) \mathrm{x}$ days after sowing $(\mathrm{C})$. 


\section{DISCUSSION}

With diminishing substrate water content, the plants of $C$. adamantium showed less development of their aerial portions (principally at $25 \%$ WRC) when grown on all substrates. Similar results were reported by Cabral et al. (2014) in their study of the growth of young Tabebuia aurea (Manso) Benth. \& Hook. f. ex S. Moore plants (ipêamarelo) subjected to watering regimes of $100 \%$, $50 \%$, and $25 \%$ of field capacity. Scalon et al. (2011) likewise observed that de Guazuma ulmifolia (mutambo) plants cultivated at $12.5 \%, 25 \%, 50 \%$, and $100 \%$ field capacity showed less development of aerial portions as the substrate water content was reduced.

Water deficits not only reduced the sizes of the individual leaves but also decreased the NL and the growth rates of the stems. The reduction in the NL in plants subjected to water stress may be considered part of the plant's survival strategy under adverse conditions because leaf loss will reduce subsequent water losses due to transpiration (KOZLOWSKI, 1976; TAIZ and ZEIGER, 2013). Adaptability to and tolerance of water stress conditions are intrinsic strategies of many different plant species (CARVALHO and CASALI, 1999), and the observed behavior of guavira indicated that low water availability reduces the growth rates of these plants and their production of green and dry above-ground biomasses.

The SPAD value was reduced as the substrate water content was lowered and for plants grown on the LS+BIO substrate at high water saturation levels (100\% WRC), indicating that these levels were not optimal for maintaining high chlorophyll indices in the leaves. The stress caused by water deficit is usually characterized by loss of chlorophyll and progressive decline in photosynthetic capacity of the plants; hence, analysis of photosynthetic pigments enables the evaluation of the activity and integrity of the internal cell apparatus during the process of photosynthesis (RONG-HUA et al., 2006; SILVA et al, 2014). The decrease in chlorophyll can be attributed to increased activity of chlorophyllase, which has been observed in conditions of water stress (SUDHAKER et al., 1997; GHOLAMI et al., 2012).

Silva et al. (2014) found that reductions in the content of chlorophyll a, chlorophyll b, and total chlorophyll are directly related to the sensitivity of cultivars of sugar cane to water deficits, and the total chlorophyll content is directly correlated with the SPAD index, which is also reduced in response to water deficit in some cultivars. The authors attributed this reduction to possible damage to the photosynthetic system, and the reduction in chlorophyll b may lead to photo-inhibition and decreased photosynthetic efficiency.

Water deficiencies provoked distinct reductions in RDW in $C$. adamantium. The reduced availability of water in the soil decreased water absorption by the plants, leading to impaired cell expansion, stomatal closure, and poor photosynthesis, thereby affecting the production of shoot and root biomasses (TAIZ and ZEIGER, 2013). The greatest increase in RDW was observed in plants grown on LS+BIO substrate at $71.45 \%$ WRC; this may be attributed to the characteristics of this substrate, as its loosely compacted and highly porous nature favors aeration and stimulates root growth (BRANDÃO et al., 2003).

Similar results were observed with $C$. ferrea (pau-ferro) seedlings (LENHARD et al., 2010) cultivated at $70 \%, 40 \%$, and $12.5 \%$ field capacity and under saturation conditions; with Myracrodruon urundeuva (aroeira) seedlings (FIGUEIRÔA et al., 2004 ) cultivated at $75 \%, 50 \%$, and $25 \%$ field capacity; and with Guazuma ulmifolia (mutambo) seedlings (SCALON et al., 2011) cultivated at $100 \%, 50 \%, 25 \%$, and $12.55 \%$ field capacity.

The presence of vermiculite (LS+BIO) in the substrates resulted in high water absorption and retention capacities, which positively influenced all of the analysis for the species. Although semidecomposed poultry manure (LS+S+PM1 and $\mathrm{LS}+\mathrm{S}+\mathrm{PM} 2)$ is often used as a source of organic material in preparing substrates for many plant cultures, this substrate was observed to have negative effects on seedlings production in the present work.

The reduced survival rates of $C$. adamantium seedlings in the LS+S+PM1 and $\mathrm{LS}+\mathrm{S}+\mathrm{PM} 2$ substrates may have been influenced by micronutrient deficiencies (data not shown) due to the high concentration of phosphorous associated with high $\mathrm{pH}$ values in substrates containing semidecomposed poultry manure (Table 1). According to Taiz and Zaiger (2013), $\mathrm{H}_{2} \mathrm{PO}_{2}{ }^{-}$ions will bind to soil particles containing positively charged aluminum or iron ions $\left(\mathrm{Fe}^{2+}, \mathrm{Fe}^{3+}\right.$, and $\left.\mathrm{Al}^{3+}\right)$ that have exchangeable hydroxyl groups $\left(\mathrm{OH}^{-}\right)$. As a result, the phosphate will be strongly bound and of low availability in the soil, thus limiting plant growth.

The DQI measures seedling quality and the equilibrium between their biomass components, with larger index values indicating better seedling quality (GOMES et al., 2002; FONSECA et al., 
2002; BERNADINO et al., 2005; SCALON and JEROMINI, 2013). Seedlings grown under water deficit conditions exhibited dramatic reductions in DQI values, indicating that water stress conditions were detrimental to seedlings production.

\section{CONCLUSIONS}

The $\mathrm{LS}+\mathrm{S}$ and $\mathrm{LS}+\mathrm{BIO}$ substrates at WRCs between $75 \%$ and $100 \%$ were most ideal for producing Campomanesia adamantium seedlings.

Growing conditions with water retention capacities of $25 \%$ and $50 \%$ should not be used to produce seedlings of this species.

RESUMO: As informações sobre à germinação, desenvolvimento de mudas, tipos de substratos e disponibilidades hídricas de espécies nativas do Cerrado ainda são escassas, para fins de propagação e estabelecimentos de plantios. Com base nisso, foram avaliados o crescimento inicial de mudas de Campomanesia adamantium semeadas em vasos contendo substrato com diferentes composições e capacidade de retenção de água: latossolo vermelho; latossolo vermelho + Bioplant $^{\circledR}(1: 1)$; latossolo vermelho + areia + esterco de frango semi- decomposto (1:1:0,5); latossolo vermelho + areia (1:1) e latossolo vermelho + areia + esterco de frango semi- decomposto (1:2:0.5). Os vasos foram irrigados por três vezes por semana para $25 \%, 50 \%, 75 \%$ e $100 \%$ da sua capacidade de retenção de água. As características morfológicas das mudas e seus índices de qualidade foram analisados 52, 83, 114 e 145 dias após a semeadura. Todas as possíveis combinações de substratos e porcentagens de capacidade de retenção de água foram feitas, com quatro repetições (12 vasos). Os substratos latossolo vermelho + areia e latossolo vermelho + Bioplant ${ }^{\circledR}$ na capacidade de retenção de água entre $75 \%$ e $100 \%$ foram encontrados para ser mais adequado para o crescimento e desenvolvimento de plântulas de $C$. adamantium. Condições de cultivo em capacidade de retenção de água de 25 e $50 \%$ não deve ser utilizado para a produção de mudas de $C$. adamantium.

PALAVRAS-CHAVE: Myrtaceae. Guavira. Cerrado. Estresse hídrico.

\section{REFERENCES}

ALEXANDRE, R. S.; WAGNER JUNIOR, A.; NEGREIROS, J. R. S.; BRUCKNER, C. H. Estádio de maturação dos frutos e substratos na germinação de sementes e desenvolvimento inicial de plântulas de jabuticabeira. Revista Brasileira de Agrociência, Pelotas, v. 12, n. 2, p. 227-230, 2006

BERNARDINO, D. C. S.; PAIVA, H. N.; NEVES, J. C. L.; GOMES, J. M.; MARQUES, V. B. Crescimento e qualidade de mudas de Anadenanthera macrocarpa (Benth.) Brenan em resposta à saturação por bases do substrato. Revista Árvore, Viçosa, v. 29, n. 6, p. 863-870, 2005

BRAGA, J. M.; DEFELIPO, B. V. Determinação espectrofotométrica de fósforo em extratos de solo e material vegetal. Revista Ceres, Viçosa, v. 21, n. 113, p. 73-85, 1974.

BRANDÃO, V. S.; PRUSKI, F. P.; SILVA, D. D. Infiltração da água no solo. Viçosa, UFV, 2003. 98 p.

CABRAL, E. L.; BARBOSA, D. C. A.; SIMABUKURO, E. A. Crescimento de plantas jovens de Tabebuia aurea (Manso) Benth. \& Hook. f. ex S. Moore submetidas a estresse hídrico. Acta Botanica Brasilica, São Paulo, v. 18, n. 2, p. 241-251, 2004. http://dx.doi.org/10.1590/S0102-33062004000200004

CARVALHO, L. M.; CASALI, V. W. D. Plantas medicinais e aromáticas: relações com luz, estresse e insetos. Viçosa: Universidade Federal de Viçosa, Departamento de Fitotecnia, 1999.

CHAVES, M. M.; PEREIRA, J. S.; MAROCO, J.; RODRIGUES, M. L.; RICARDO, C. P. P.; OSÓRIO, M. L.; CARVALHO, I.; FARIA, T.; PINHEIRO, C. How plants cope with water stress in the field? Photosynthesis and growth. Annals of Botany, London, v. 89, n. 2-3, p. 907-916, 2002.

DICKSON, A.; LEAF, A. L.; HOSNER, J. F. Quality apprasial of withe spruce and White pine seedling stock in nurseries. Forest Chronicle, Ontario, v. 36, n. 1, p. 10-13, 1960. http://dx.doi.org/10.5558/tfc36010-1 
FERREIRA, D. F. SISVAR: um programa para análises e ensino de estatística. Revista Symposium, Lavras, n. 6, p. 36-41, 2008.

FIGUEIRÔA, J. M.; BARBOSA, D. C. A.; SIMABUKURO, E. A. Crescimento inicial de plantas jovens de Myracrodruon urundeuva Allemão (Anacardiaceae) sob diferentes regimes hídricos. Acta Botânica Brasílica, São Paulo, v. 18, n. 3 p. 573-580, 2004.

FLOSS, E. L. Fisiologia das plantas cultivadas. Passo Fundo-RS: UPF, ed. 4, 749 p., 2008.

FONSECA, É. P.; VALÉRI, S. V.; MIGLIORANZA, É.; FONSECA, N. A. N.; COUTO, L. Padrão de qualidade de mudas de Trema micrantha (L.) Blume, produzidas sob diferentes períodos de sombreamento. Revista Árvore, Viçosa, v. 26, n. 4, p. 515-523, 2002.

GHOLAMI, M.; RAHEMI, M.; RASTEGAR, S. Use of rapid screening methods for detecting drought tolerant cultivars of fig (Ficus carica L.). Scientia Horticulturae, Amsterdam, v. 143, p. 7-14, 2012.

http://dx.doi.org/10.1016/j.scienta.2012.05.012

GOMES, J. M.; COUTO, L.; LEITE, H. G.; XAVIER, A.; GARCIA, S. L. R. Parâmetros morfológicos na avaliação da qualidade de mudas de Eucalyptus grandis. Revista Árvore, Viçosa, v. 26, n. 6, p. 655-664, 2002.

JACKSON, M. L. Análisis quimico de suelos. 3. ed. Barcelona: EDICIONES OMEGA, 1976. 662p.

KIEHL, E. J. Manual de edafologia. São Paulo: Ceres, 1979. p. 191-215.

KOZLOWSKI, T. I. Water supply and leaf shedding. In: Water stress and plant growth. New York; Academic Press, n. 4, p. 191-222, 1976. http://dx.doi.org/10.1016/b978-0-12-424154-1.50011-5

LARCHER, W. Ecofisiologia Vegetal, São Carlos: Rima, 2006, 550p.

LENHARD, N. R.; SCALON, S. P. Q.; NOVELINO, J. O. Crescimento inicial de mudas de pau ferro (Caesalpinia ferrea Mart. ex tul. var. leiostachya Benth.) sob diferentes regimes hídricos. Ciência e Agrotecnologia, Lavras, v. 34, n. 4, p. 870-877, 2010.

MEDRI, M. E. Estudos sobre a tolerância ao alagamento em espécies arbóreas nativas da bacia do rio Tibagi. Londrina: [s.n.], 2002. 172p.

OLIVEIRA, V. C.; JOLY, C. A. 2010. Flooding tolerance of Calophyllum brasiliense Camb. (Clusiaceae): morphological, physiological and growth responses. Trees, Berlin, v. 24, n. 1, p. 185-193, 2010. http://dx.doi.org/10.1007/s00468-009-0392-2

RONG-HUA, L. I.; PEI-POL, G, U. O.; BAUMZ, M.; GRANDO, S.; CECCARELLI, S. Evaluation of chlorophyll content and fluorescence parameters as indicators of drought tolerance in barley. Agricultural Sciences in China, v. 5, n. 10, p. 751-757, 2006.

SANTOS, B. R.; PAIVA, R.; DOMBROSKI, J. L. D.; MARTINOTO, C.; GUEIRA, R. C.; SILVA, A. A. N. Pequizeiro (Caryocar brasiliense Camb.): uma espécie promissora do Cerrado Brasileiro. Lavras: UFLA, 2006. 33p. (Boletim Agropecuário, 66).

SCALON, S. P. Q.; OSHIRO, A. M.; MASETTO, T. E.; DRESCH, D. M. Conservation of Campomanesia adamantium (Camb.) O Berg seeds in different packaging and at varied temperatures. Revista Brasileira de Fruticultura, Jaboticabal, v. 35, p. 262-269, 2013.

SCALON, S. P. Q.; JEROMINI, T. S. Substratos e níveis de água no potencial germinativo de sementes de uvaia. Revista Árvore, Viçosa, v. 37, p. 49-58, 2013. 
SCALON, S. P. Q.; MUSSURY, R. M.; EUZÉBIO, V. L. M.; KODAMA, F. M.; KISSMANN, C. Estresse hídrico no metabolismo e crescimento inicial de mudas de mutambo (Guazuma ulmifolia Lam.). Ciência Florestal, Santa Maria, v. 21, p. 657-664, 2011.

SILVA, M. A.; SANTOS, C. M.; VITORINO, H. S.; RHEIN, A. F. L. Pigmentos fotossintéticos e índice SPAD como descritores de intensidade do estresse por deficiência hídrica em cana-de-açúcar. Bioscience Journal, Uberlândia, v. 30, n. 1, p. 173-181, 2014

SOUZA, C. C.; OLIVEIRA, F. A.; SILVA, I. F.; AMORIM NETO, M. S. Avaliação de métodos de determinação de água disponível e manejo da irrigação em terra roxa sob cultivo de algodoeiro herbáceo.

Revista Brasileira de Engenharia Agrícola e Ambiental, Campina Grande, v. 4, n. 3, p. 338-342, 2000. http://dx.doi.org/10.1590/S1415-43662000000300006

SUDHAKAR, C.; RAMANJULU, S.; REDDY, O. S.; VEERANJANEYULU, K. Response of some calvin cycle enzymes subjected to salinity shock in vitro. Indian Journal of Experimental Biology, New Delhi, v. 35, n. 6, p. 665-667, 1997.

TAIZ, L.; ZEIGER, E. Fisiologia Vegetal. 5. ed. Porto Alegre: Artmed, 2013, 918 p.

TRAZZI, P. A.; CALDEIRA, M. V. W.; COLOMBI, R.; PERONI, L.; GODINHO, T. O. Estercos de origem animal em substratos para a produção de mudas florestais: atributos físicos e químicos. Scientia Forestalis, Piracicaba, v. 40, n. 96, p. 455-462, 2012.

VETTORI, L. Métodos de análise de solo. Rio de Janeiro: Equipe de pedologia e fertilidade do solo, 1969. 24 p. (Boletim técnico, 7).

WAGNER JUNIOR, A.; ALEXANDRE, R. S.; NEGREIROS, J. R. S.; PIMENTEL, L. D.; COSTA E SILVA, J. O.; BRUCKNER, C. H. Influência do substrato na germinação e desenvolvimento inicial de plantas de maracujazeiro amarelo (Passiflora edulis Sims f. flavicarpa Deg). Ciência e Agrotecnologia, Lavras, v. 30, n. 4, p. 643-647, 2006. 